\title{
Feline platynosomiasis: analysis of the association of infection levels with pathological and biochemical findings
}

Platinossomiase felina: análise da associação dos níveis de infecção com achados patológicos e bioquímicos

Dirceu Guilherme de Souza Ramos ${ }^{1,2}$; Amanda Raiza Gonçalves Lima Oliveira Santos ${ }^{3}$; Leodil da Costa Freitas ${ }^{3}$; Ísis Assis Braga² ${ }^{2}$ Erica Pereira da Silva³ ${ }^{3}$ Luciana Maria Curtio Soares ${ }^{3}$; Nádia Aline Bobbi Antoniassi;

Fernando Henrique Furlan; Richard de Campos Pacheco ${ }^{3 *}$

\author{
${ }^{1}$ Unidade Acadêmica Especial de Ciências Agrárias, Universidade Federal de Goiás - UFG, Jataí, GO, Brasil \\ ${ }^{2}$ Instituto de Ciências Agrárias, Centro Universitário de Mineiros - UNIFIMES, Mineiros, GO, Brasil \\ ${ }^{3}$ Faculdade de Medicina Veterinária, Universidade Federal de Mato Grosso - UFMT, Cuiabá, MT, Brasil \\ ${ }^{4}$ Instituto de Ciências da Saúde, Universidade Federal de Mato Grosso - UFMT, Sinop, MT, Brasil
}

Received October 18, 2016

Accepted February 2, 2017

\begin{abstract}
Platynosomiasis is a common feline hepatic disease caused by Platynosomum fastosum (Trematoda - Dicrocoelidae), which is also known as 'lizard poisoning'. Most reports of feline platynosomiasis show that this disease is sporadic and manifests with uncommon lesions; its pathogenicity is still not well understood. This study aimed to describe liver injuries and enzymatic changes associated with natural $P$. fastosum infection in 47 stray cats in an endemic area. Overall, 38.3\% (18/47) of cats were parasitized, and 2,358 flukes (P. fastosum) were collected (131 - mean intensity of parasitism; 50.2 - mean abundance). The alanine transaminase (ALT) measure was significantly higher in parasitized animals, while alkaline phosphatase (ALP) showed no statistical difference between parasitized and non-parasitized animals. In infected animals, gross pathological lesions and microscopic liver injuries ranged from mild to severe, and were similar to those in previous descriptions of feline platynosomiasis. Nonetheless, the intensity of parasitism was not related to the severity of macroscopic or microscopic hepatic injuries. However, feline platynosomiasis should be considered in the differential diagnosis of feline liver disorders, as well as, in any program of helminth control, even if no clinical abnormalities are present.
\end{abstract}

Keywords: Platynosomum fastosum, liver, lesions, ALT, ALP.

\section{Resumo}

Platinossomiase é uma doença hepática felina comum causada por Platynosomum fastosum (Trematoda - Dicrocoelidae), também é conhecida como "envenenamento por lagartixa". A maioria dos relatos de platinossomiase felina mostra que esta doença é esporádica e se manifesta com lesôes incomuns; sua patogenicidade ainda não é bem compreendida. Este estudo objetivou descrever as lesōes no fígado e alterações enzimáticas associadas à infecção natural por $P$. fastosum em 47 gatos errantes em uma área endêmica. No total, 38,3\% (18/47) dos gatos estavam parasitados, e 2.358 trematódeos (P. fastosum) foram coletados (131 - intensidade média de parasitismo; 50,2 - abundância média). A quantidade de alanina transaminase (ALT) foi significativamente maior nos animais parasitados, enquanto a fosfatase alcalina (ALP) nấo apresentou diferença estatística entre os animais parasitados e não parasitados. Nos animais infectados, lesões patológicas macroscópicas e microscópicas hepáticas variaram de leve a grave, e foram semelhantes a descrições anteriores de platinossomiase felina. No entanto, a intensidade do parasitismo não foi relacionada à gravidade das lesóes hepáticas macroscópicas ou microscópicas. Contudo, a platinossomiase felina deve ser considerada no diagnóstico diferencial de distúrbios hepáticos em felinos, assim como, em qualquer programa de controle de helmintos, mesmo que nenhuma anormalidade clínica esteja presente.

Palavras-chaves: Platynosomum fastosum, fígado, lesôes, ALT, ALP. 


\section{Introduction}

Platynosomiasis is a common hepatic disease in cats caused by Platynosomum fastosum, Looss, 1907 (Trematoda - Dicrocoelidae), which is also known as 'lizard poisoning' (CATCOTT, 1964). These liver flukes are found in tropical and sub-tropical regions and parasitize cats from the Pacific Islands, North America, South America, the Caribbean, Africa, Asia, and Oceania (BASU \& CHARLES, 2014). A previous study described $P$. fastosum, $P$. concinnum and P. illiciens as synonymous and all affect the liver, gallbladder, and bile ducts in cats (MALDONADO, 1945). The life cycle involves the terrestrial mollusk Subulina octona (ASH, 1962), as the first intermediate host, and reptiles and amphibians (MALDONADO, 1945) as paratenic hosts. Isopods can also be involved in the direct transmission of the parasite to the definitive or paratenic hosts, especially in South America (PINTO et al., 2014).

The importance of platynosomiasis in feline medicine is in strong contrast with the scarcity of studies describing the diagnosis and clinical presentation of this disease (RAMOS et al., 2013; BRAGA et al., 2016). The most common microscopic lesions include cholangiectasis, cholangiohepatitis, atrophy of hepatocytes, and hyperplasia of the biliary duct epithelium, which results in thickening of the liver, fatty infiltration of hepatocytes, sections of flukes and/or eggs in the liver, and abundant hepatic infiltration of leukocytes and eosinophils (BASU \& CHARLES, 2014). However, most cases of platynosomiasis in cats have been described as incidental findings during necropsies (O'SULLIVAN et al., 1976; HANEY et al., 2006; XAVIER et al., 2007; CARREIRA et al., 2008; LENIS et al., 2009; ANDRADE et al., 2012). Therefore, the present study aimed to describe the macroscopic and microscopic liver injuries associated with natural $P$. fastosum infection in stray cats in an endemic area of midwestern Brazil, and to investigate an association between parasite burden and pathological and biochemical findings.

\section{Materials and Methods}

From January to July 2014, 47 adult (20 males and 27 females) stray cats (Felis silvestris catus, Linnaeus, 1758) from Várzea Grande municipality, Mato Grosso State in midwestern Brazil, classified according to dental development, maturation of genital structure and body size (SHARIF et al., 2007) were subjected to necropsy procedures. These animals were received or captured by the Zoonosis Control Center (CCZ) and then euthanized according to the protocol of the American Veterinary Medical Association (AVMA) Guidelines on Euthanasia (AVMA, 2001). During necropsy, the liver and gallbladder were completed cut and the bile duct was mechanically expressed through a sieve $(0.15 \mathrm{~mm})$ to expel any flukes present (RODRÍGUEZ-VIVAS et al., 2004). All content was analyzed using a stereomicroscope under $10 \times$ magnification (RAMOS et al., 2013). Fragments of the distal portion of the right middle liver lobe were fixed in $10 \%$ formalin, submitted for routine processing techniques, and stained by hematoxylin-eosin for histopathological examination (PROPHET et al., 1992). Before euthanasia, blood serum samples were collected and serum enzyme concentrations of alanine transaminase (ALT) and alkaline phosphatase (ALP) were assayed.

The sample size was assessed considering the prevalence of 26\% (RAMOS et al., 2013) with 95\% confidence level and 5\% statistical error. Prevalence, mean intensity of parasitism (MIP), and mean abundance (MA) were calculated as described by Bush et al. (1997). Mean intensity statistical analysis were performed using the methodology of generalized linear models (GLM) and the statistical package R (R DEVELOPMENT CORE TEAM, 2011) by comparing presence of injuries. For variable mean intensity, Poisson distribution (count of individuals) was used, with the logarithmic link function as a linear predictor. Serum enzyme concentrations of ALT and ALP from cats infected with P. fastosum were also compared using the Wilcoxon-Mann-Whitney test.

The Bioethical Committee for Animal Research of the Federal University of Mato Grosso approved the present study, under protocol no. 23108.011507/13-4.

\section{Results}

In total, $38.3 \%(18 / 47)$ of cats ( 8 males and 10 females) were parasitized by $P$. fastosum with no gender-specific association. There was a significant increase of serum activity of the hepatic enzyme ALT (reference range: 6-83 U/L; JAIN, 1993) in parasitized animals $(\mathrm{p}$-value $=0.029)$, while ALP showed no statistical difference from the normal values (Table 1). Overall, 2,358 flukes were collected (131-MIP; 50.2-MA), and cats harboring liver flukes showed different levels of infection: in $72.2 \%$ (13/18) of cats, less than 40 P. fastosum were found per animal; in $16.7 \%(3 / 18)$, more than 500 parasites/cat were observed; and in $11.1 \%(2 / 18)$ 147 (cat number 8) and 300 (cat number 15) flukes were found, as shown in Table 2 .

Macroscopic characteristics observed in livers infected with P. fastosum were extrahepatic and intrahepatic bile duct distension (Figure 1) in $61.1 \%(11 / 18)$ of livers sampled, visualization of bile ducts on the hepatic surface due to wall thickening of the bile duct in $33.3 \%(6 / 18)$, and jaundice in 16.7\% (3/18) (Table 2). Furthermore, $P$. fastosum were also observed in the gallbladder and bile ducts (Figure 1) in 44.4\% (8/18) of livers (Table 2), during necropsy.

All histological changes are showed in Table 3, and the most common microscopic lesions observed in 94.4\% (17/18) of the livers from infected cats included: periportal proliferation of the bile ducts; periportal fibrosis, and sometimes bridging fibrosis; periportal cholangitis consisting of infiltrates of lymphocytes, plasmocytes and eosinophils; and cholangioectasis (Figure 2).

Table 1. Mean amount (U/L) of alanine transaminase (ALT) and alkaline phosphatase (ALP) from stray cats from Várzea Grande municipality, midwestern Brazil, naturally parasitized and non-parasitized with Platynosomum fastosum.

\begin{tabular}{cccc}
\hline \multirow{2}{*}{$\begin{array}{c}\text { Enzymes } \\
(\mathbf{U} / \mathbf{L})\end{array}$} & \multicolumn{2}{c}{ Parasitism } & \multirow{2}{*}{ P-value } \\
\cline { 2 - 3 } & Yes & No & \\
\hline ALT & 92.6 & 66.5 & 0.029 \\
ALP & 26.9 & 23.6 & 0.982 \\
\hline
\end{tabular}


Table 2. Macroscopic characteristics of livers from cats naturally parasitized with Platynosomum fastosum of Várzea Grande municipality, midwestern Brazil.

\begin{tabular}{|c|c|c|c|c|c|c|}
\hline Animal & $\begin{array}{c}\text { Intensity of } \\
\text { parasitism }\end{array}$ & Jaundice & $\begin{array}{l}\text { Visualization of bile ducts } \\
\text { on the hepatic surface }\end{array}$ & $\begin{array}{l}\text { Extrahepatic ducts } \\
\text { distension }\end{array}$ & $\begin{array}{l}\text { Intrahepatic ducts } \\
\text { distension }\end{array}$ & $\begin{array}{l}\text { Parasites in ducts/ } \\
\text { gallbladder }\end{array}$ \\
\hline 1 & 29 & + & ++ & +++ & +++ & + \\
\hline 2 & 642 & 0 & 0 & + & + & +++ \\
\hline 3 & 8 & 0 & ++ & ++ & ++ & 0 \\
\hline 4 & 1 & 0 & 0 & 0 & 0 & 0 \\
\hline 5 & 13 & 0 & 0 & 0 & 0 & 0 \\
\hline 6 & 4 & 0 & 0 & 0 & 0 & 0 \\
\hline 7 & 8 & 0 & 0 & 0 & 0 & 0 \\
\hline 8 & 147 & + & ++ & +++ & +++ & 0 \\
\hline 9 & 23 & 0 & 0 & + & + & + \\
\hline 10 & 39 & 0 & 0 & + & + & + \\
\hline 11 & 519 & 0 & ++ & ++ & ++ & +++ \\
\hline 12 & 560 & 0 & 0 & + & + & +++ \\
\hline 13 & 8 & 0 & + & ++ & ++ & 0 \\
\hline 14 & 9 & 0 & 0 & 0 & 0 & 0 \\
\hline 15 & 300 & + & ++ & +++ & +++ & +++ \\
\hline 16 & 15 & 0 & 0 & 0 & 0 & 0 \\
\hline 17 & 6 & 0 & 0 & 0 & 0 & 0 \\
\hline 18 & 31 & 0 & 0 & + & + & + \\
\hline
\end{tabular}

$0=$ absent $;+=$ mild $;++=$ moderate $;+++=$ severe .

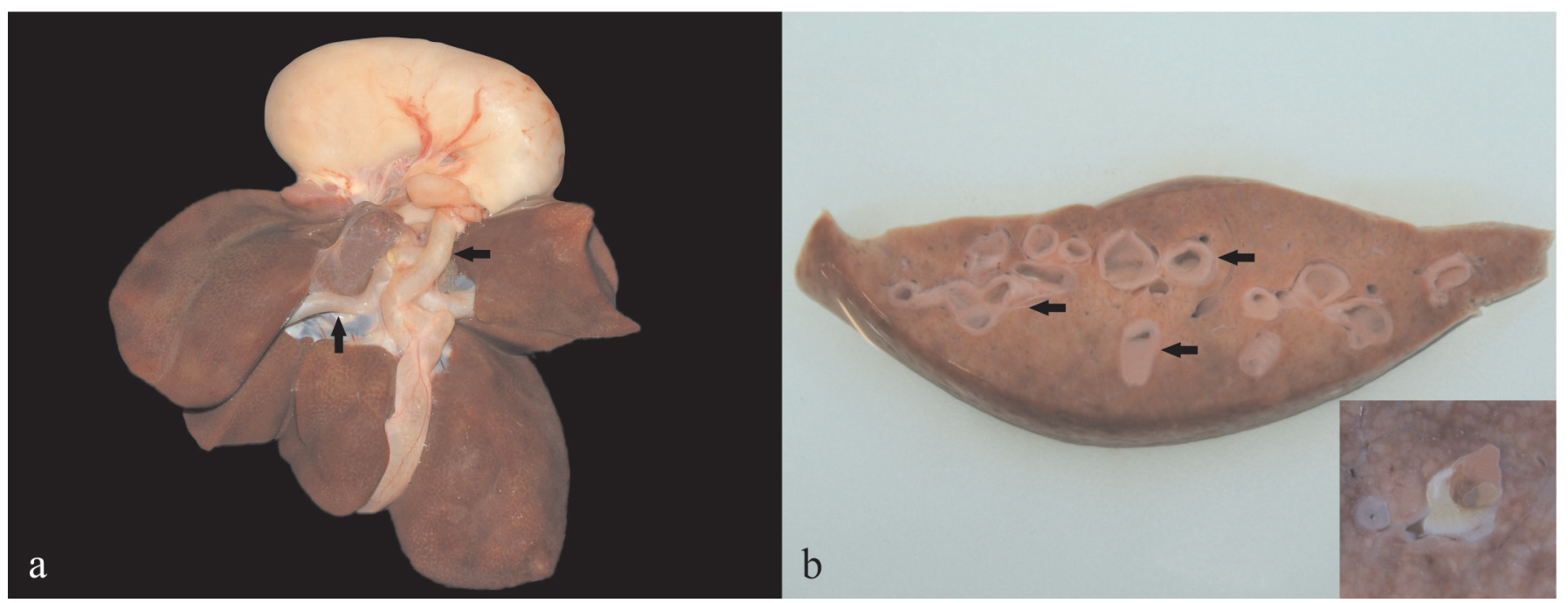

Figure 1. Macroscopic lesions of livers from cats from Várzea Grande municipality, midwestern Brazil, naturally parasitized with Platynosomum fastosum. (a) Liver of Cat 1 with severe extra hepatic bile duct distension. (b) Liver cut surface of Cat 8 showing multifocal severe intrahepatic bile duct distension. Inset: liver cut surface of Cat 15 showing two specimens of Platynosomum fastosum in the lumen of a distended bile duct.

Additionally, hyperplasia of bile duct epithelium (Figure 2) was seen in $83.3 \%(15 / 18)$ of samples, while cholestasis was observed in lower frequency $(16.7 \%$ [3/18]) as noted in Table 3. Cross-sections of adult $P$. fastosum (Figure 2) were seen in bile ducts/gallbladders of $27.8 \%(5 / 18)$ of livers (Table 3). Adult trematodes were characterized (BASU \& CHARLES, 2014) by a thin cuticle without spines, no celomatic cavity, oral and ventral suckers, intestines, testes, ovaries vitellaries and uterus; operculated eggs were observed throughout delimitation of the uterus (Figure 2). No association was observed between the severity of the macroscopic or microscopic hepatic lesions and the parasitic burden by $P$. fastosum.

Statistical analysis showed no significant relationship between mean intensity of parasitism and presence of injuries (jaundice, $\mathrm{p}=0.1941$; visualization of the bile ducts on the hepatic surface, $\mathrm{p}=0.3308$; extrahepatic bile ducts distension, $\mathrm{p}=0.1050$; intrahepatic bile duct distension, $\mathrm{p}=0.1050$; periportal proliferation of bile ducts, $\mathrm{p}=0.4364$; periportal fibrosis, $\mathrm{p}=0.4364$; cholestasis, $\mathrm{p}=0.1512$; hyperplasia of the bile duct epithelium, $\mathrm{p}=0.5846$; cholangiectasis, $\mathrm{p}=0.4364$; periportal cholangitis, $\mathrm{p}=0.4364$ ). 
Table 3. Histologic characteristics of livers from cats naturally parasitized with Platynosomum fastosum of Várzea Grande municipality, midwestern Brazil.

\begin{tabular}{|c|c|c|c|c|c|c|c|}
\hline Animal & $\begin{array}{c}\text { Periportal proliferation } \\
\text { of bile ducts }\end{array}$ & $\begin{array}{l}\text { Periportal } \\
\text { fibrosis }\end{array}$ & Cholestasis & $\begin{array}{l}\text { Hyperplasia of the } \\
\text { bile duct epithelium }\end{array}$ & Cholangiectasis & $\begin{array}{l}\text { Periportal } \\
\text { cholangitis }\end{array}$ & $\begin{array}{c}\text { Parasites } \\
\text { (Histological) }\end{array}$ \\
\hline 1 & + & + & 0 & + & +++ & + & + \\
\hline 2 & + & + & 0 & + & + & + & 0 \\
\hline 3 & ++ & ++ & + & ++ & ++ & ++ & + \\
\hline 4 & 0 & 0 & + & 0 & 0 & 0 & 0 \\
\hline 5 & ++ & ++ & + & + & + & ++ & 0 \\
\hline 6 & + & + & 0 & + & + & + & 0 \\
\hline 7 & +++ & ++ & 0 & + & + & ++ & 0 \\
\hline 8 & +++ & ++ & 0 & ++ & +++ & ++ & + \\
\hline 9 & + & + & 0 & 0 & + & + & 0 \\
\hline 10 & + & + & 0 & 0 & + & + & 0 \\
\hline 11 & ++ & ++ & 0 & ++ & ++ & + & + \\
\hline 12 & + & + & 0 & + & + & + & 0 \\
\hline 13 & + & ++ & 0 & + & ++ & + & 0 \\
\hline 14 & + & ++ & 0 & + & + & + & 0 \\
\hline 15 & +++ & + & 0 & +++ & +++ & ++ & + \\
\hline 16 & + & + & 0 & + & + & + & 0 \\
\hline 17 & + & + & 0 & + & + & + & 0 \\
\hline 18 & + & + & 0 & + & + & + & 0 \\
\hline
\end{tabular}

0 = absent + = mild $++=$ moderate $+++=$ severe .

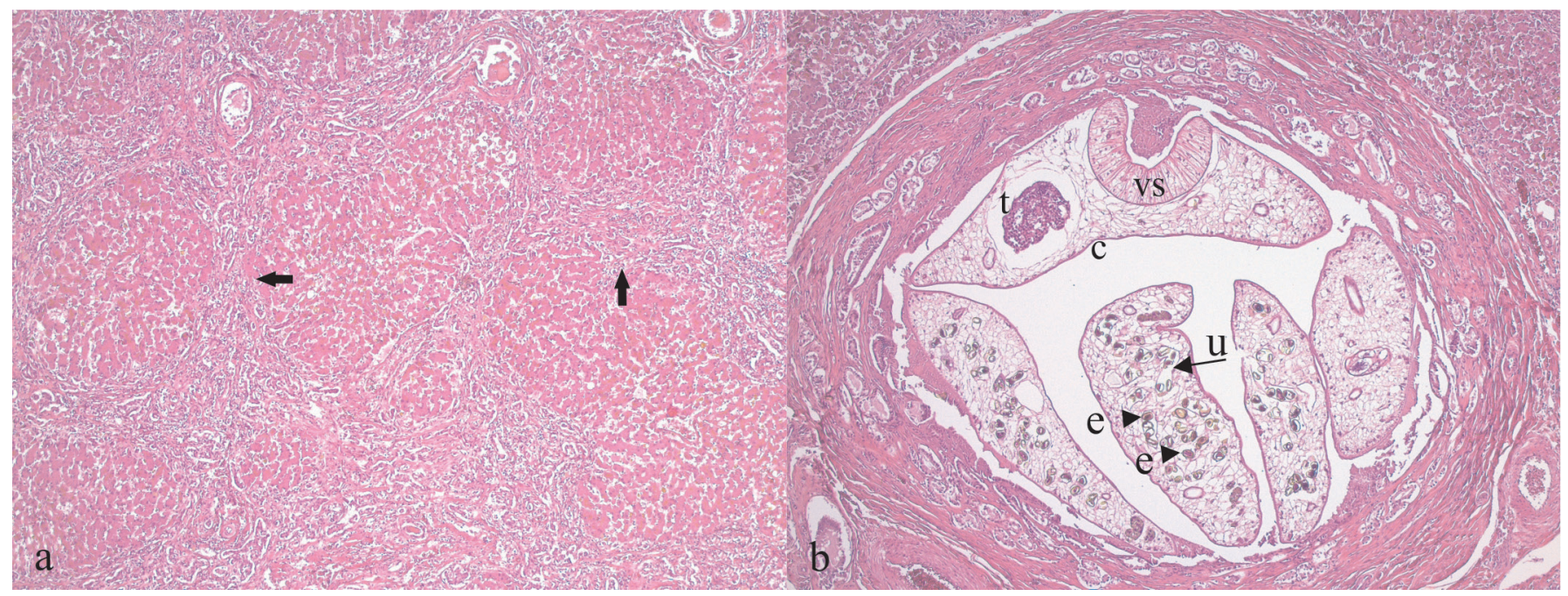

Figure 2. Microscopic lesions of livers from cats naturally parasitized with Platynosomum fastosum of Várzea Grande municipality, midwestern Brazil. (a) Liver of Cat 8 showing periportal fibrosis forming bridges between portal areas, proliferation of bile ducts, periportal cholangitis and cholangioectasis. Hematoxylin and eosin (10x objective lens). (b) Liver of Cat 8 showing periportal proliferation of the bile ducts, periportal fibrosis, severe cholangioectasis and four specimens of $P$. fastosum in the lumen of the distended bile duct. One of them is attached to the bile duct epithelium. Note the parasite thin cuticle without spines (c), no celomatic cavity, ventral sucker (vs), testes ( $\mathrm{t}$ ) and uterus ( $\mathrm{u}$ ) with eggs (e). Hematoxylin and eosin (10x objective lens).

\section{Discussion}

Prevalence of the liver fluke, P. fastosum, in cats has been described as ranging from 0.07 to $81 \%$ worldwide (BASU \& CHARLES, 2014). In Brazil, the occurrence of parasitic infection with $P$. fastosum is commonly described as being related to sporadic cases of liver disorders (XAVIER et al., 2007; CARREIRA et al., 2008; ANDRADE et al., 2012), and few previous surveys having determined the prevalence or frequency of occurrence of $P$. fastosum in cats. Ferreira et al. (1999) observed 37.27\% of prevalence in Rio de Janeiro, southeast Brazil, Ramos et al. (2013) 26.03\% in Mato Grosso, midwest Brazil, while Braga et al. (2016) showed overall prevalence of $P$. fastosum in free roaming domestic cats of $42.6 \%$ in Ceará, northeast Brazil. According to Braga et al. (2016) many of these observed prevalences could have been higher, if a more sensitive diagnostic method had been used. The authors observed 
that bile microscopic egg detection was shown to be 1.6 times more sensitive than manual collection of trematodes by necropsy. Here, we described a higher prevalence $(38.3 \%)$ of $P$. fastosum in stray cats compared to that in a previous study (RAMOS et al., 2013), performed in the same study area. This may be attributed to the sample population (adult stray cats), as animals aged 2 years or older are more frequently infected (FOLEY, 1994; RODRIGUEZ-VIVAS et al., 2004; SALOMÁO et al., 2005; BRAGA et al., 2016). Furthermore, free living cats have a higher probability of being infected with any of the intermediate hosts (SALOMÃO et al., 2005; ANDRADE et al., 2012). Considering that platynosomiasis has been frequent among stray cats in the study area, it should be considered as a differential diagnosis in feline liver disorders (RAMOS et al., 2013), as well as, in helminth control programs, mainly in adult stray cats, even if no clinical abnormalities are present.

Signs of hepatic dysfunction have been reported including changes in serum ALT, with ALP usually remaining unaffected (FOLEY, 1994; TAYLOR \& PERRI, 1977; CARREIRA et al., 2008). A marked increase of ALT was detected, as described in a previous study (TAYLOR \& PERRI, 1977) after 1 to 4 months in severely parasitized cats $(\sim 1,000$ flukes $)$, indicating damage to the parenchymal cells, thereby allowing leakage of the cytosol contents into circulation. As seen in other studies of feline platynosomiasis, serum ALP was within normal values (FOLEY, 1994; TAYLOR \& PERRI, 1977; CARREIRA et al., 2008). Usually, increase of ALP is associated with severe cholestasis (ALLISON, 2012), which was observed in low frequency (16.6\%), despite this clinical sign having been previously described in association to $P$. fastosum infection (HANEY et al., 2006; BRAGA et al., 2016).

Platynosomiasis is frequently considered an asymptomatic infection (TAYLOR \& PERRI, 1977; FOLEY, 1994). Previous studies have reported that the severity of clinical signs and lesions depends on the parasitic burden (TAYLOR \& PERRI, 1977; FOLEY, 1994; SALOMÃO et al., 2005). Despite Braga et al. (2016) have characterized the influence of fluke burden on the formation of lesions, and reported significant association with increasing degrees of ductular proliferation, here the same lesion was observed in $94.4 \%(17 / 18)$ of the livers from infected cats, but there was not observed association between the severity and the parasitic burden by $P$. fastosum. Unlike, in the present study severe lesions were observed in animals with low intensity of parasitism (less than 40 parasites in animals 1 and 7). Additionally, we observed cats with high parasite burdens (more than 500 flukes in animals 2 and 12) that showed mild injuries. In these cases, we believe that although these cats had a high intensity of parasitism at the time of death, they may have been only recently infected, and therefore, did not have sufficient time to develop lesions. Taylor \& Perri (1977) recovered P. fastosum from livers of experimentally infected cats after the first week; however, microscopic changes were not noticed until 3 weeks following infection, indicating that platynosomiasis is a chronic and progressive disease (FERREIRA et al., 1999; HEADLEY et al., 2012; CARREIRA et al., 2008). Another variant that must be considered is variability in individual immune responses. Hosts adapted to parasites can show no immunological response, resulting in low grade or no pathological lesions even if affected by high infestation levels. Alternately, unadapted hosts, can suffer minimal parasite infestations, but exhibit severe inflammatory responses causing accentuated lesions (SPITHILL et al., 1997).

Gross pathological lesions observed in the livers of infected cats were similar to previous descriptions of lesions in feline platynosomiasis (HANEY et al., 2006; HEADLEY et al., 2012; BASU \& CHARLES, 2014; BRAGA et al., 2016). Milder injuries such as jaundice, parasites in the bile duct and gallbladder, and visualization of bile ducts on the hepatic surface were the abnormalities most commonly observed, while bile duct distension was the most remarkable lesion present in $61.1 \%$ of livers from infected animals. Despite marked jaundice is one the main macroscopic changes described in necropsy studies (FERREIRA et al., 1999; HEADLEY et al., 2012), Braga et al. (2016) did not observed significant association of this symptom (mild jaundice) with prevalence of $P$. fastosum in free roaming domestic cats in northeastern Brazil.

The microscopic liver injuries described, ranging from mild to severe, are similar to commonly reported findings (IKEDE et al., 1971; RETNASABAPATHY \& PRATHAP, 1971; FERREIRA et al., 1999; HEADLEY et al., 2012). Histopathological comparison is difficult, since stray cats used during this study had no known medical history, and possibly with natural infections which could be ongoing for different period of times. However, we can highlight that the periportal proliferation of the bile ducts and periportal fibrotic lesions observed in $94.4 \%$ of cat livers reveal chronic exposure to P. fastosum. Taylor \& Perri (1977) noted extensive fibrous connective tissue in the bile ducts in the chronic stage (6 months after infection or beyond). Herein, we observed that naturally infected stray cats in an endemic region to platynosomiasis did not present severe pathological conditions such as cystic liver disease, severe cholestatic liver disease, cholangitis and cholangiohepatitis, cholangiocarcinoma, mesenteric lymphadenopathy, and hepatomegaly (O'SULLIVAN et al., 1976; HANEY et al., 2006; XAVIER et al., 2007; CARREIRA et al., 2008; ANDRADE et al., 2012; BRAGA et al., 2016). Morover, the intensity of parasitism was not related to the severity of macroscopic or microscopic hepatic injuries. An increase in serum ALT can be suggestive of infection by $P$. fastosum in endemic areas, where adult stray cats are chronically exposed; nonetheless, other liver diseases should be discarded.

\section{Acknowledgements}

Coordenação de Aperfeiçoamento de Pessoal de Nível Superior (CAPES) for the financial support; to Conselho Nacional de Desenvolvimento Científico e Tecnológico (CNPq) for the scholarship of R.C. Pacheco; Fundaçáo de Amparo à Pesquisa do Estado de Mato Grosso (FAPEMAT).

\section{Financial support}

Coordenação de Aperfeiçoamento de Pessoal de Nível Superior (CAPES), Conselho Nacional de Desenvolvimento Científico e Tecnológico (CNPq) and Fundação de Amparo à Pesquisa do Estado de Mato Grosso (FAPEMAT). 


\section{References}

Allison RW. Laboratory evaluation of the liver. In: Thrall MA, Weiser G, Allison RW, Campbell TW. Veterinary Hematology and Clinical Chemistry. 2nd ed. New Jersey: Wiley-Blackwell; 2012. 346 p.

American Veterinary Medical Association - AVMA. Report of the AVMA panel on Euthanasia. J Am Vet Med Assoc 2001; 218(5): 669696. PMid:11280396. http://dx.doi.org/10.2460/javma.2001.218.669.

Andrade RL, Dantas AF, Pimentel LA, Galiza GJ, Carvalho FK, Costa VM, et al. Platynosomum fastosum-induced cholangiocarcinomas in cats. Vet Parasitol 2012; 190(1-2): 277-280. PMid:22963714. http://dx.doi. org/10.1016/j.vetpar.2012.04.015.

Ash LR. Helminth parasites of dogs and cats in Hawaii. J Parasitol 1962; 48(1): 63-65. PMid:13862798. http://dx.doi.org/10.2307/3275412.

Basu AK, Charles RA. A review of the cat liver fluke Platynosomum fastosum Kossack, 1910 (Trematoda: Dicrocoeliidae). Vet Parasitol 2014; 200(1-2): 1-7. PMid:24412358. http://dx.doi.org/10.1016/j.vetpar.2013.12.016.

Braga RR, Teixeira AC, Oliveira JA, Cavalcanti LP. Prevalence of Platynosomum fastosum infection in free roaming cats in northeastern Brazil: fluke burden and grading of lesions. Vet Parasitol 2016; 227: 2025. PMid:27523932. http://dx.doi.org/10.1016/j.vetpar.2016.07.021.

Bush AO, Lafferty KD, Lotz JM, Shostak AW. Parasitology meets ecology on its own terms: Margolis et al. revisited. J Parasitol 1997; 83(4): 575583. PMid:9267395. http://dx.doi.org/10.2307/3284227.

Carreira VS, Vieira RF, Machado GF, Luvizotto MC. Feline cholangitis/ cholangiohepatitis complex secondary to Platynosomum fastosum infection in a cat. Rev Bras Parasitol Vet 2008;17(S1 Suppl 1): 184-187. PMid:20059845.

Catcott EJ. Feline Medicine and Surgery (Flukes by Renaux, E.A.). Santa Barbara: American Veterinary Publication; 1964.

Ferreira AMR, Almeida ECP, Labarthe NV. Liver fluke infection (Platynosomum concinnum) in Brazilian cats: prevalence and pathology. Feline Pract 1999; 27(2): 19-22.

Foley RH. Platynosomum concinnum infection in cats. Compend Contin Educ Pract Vet 1994; 16(10): 1271-1277.

Haney DR, Christiansen JS, Toll J. Severe cholestatic liver disease secondary to liver fluke (Platynosomum concinnum) infection in three cats. J Am Anim Hosp Assoc 2006; 42(3): 234-237. PMid:16611937. http://dx.doi.org/10.5326/0420234.

Headley SA, Gillen MA, Sanches AW, Satti MZ. Platynosomum fastosuminduced chronic intrahepatic cholangitis and Spirometra spp. infections in feral cats from Grand Cayman. J Helminthol 2012; 86(2): 209-214. PMid:21729387. http://dx.doi.org/10.1017/S0022149X11000265.

Ikede BO, Losos GJ, Isoun TT. Platynosomum concinnum infection in cats in Nigeria. Vet Rec 1971; 89(24): 635-638. PMid:5150808. http:// dx.doi.org/10.1136/vr.89.24.635.

Jain NC. Essentials of veterinary hematology. Philadelphia: Lea \& Febiger; 1993.
Lenis C, Navarro F, Velez I. First case of platinosomosis from Colombia: Platynosomum illiciens (Digenea: Dicrocoeliidae) in Felis catus, Turbo, Antioquia. Rev Colom Cienc Pecua 2009; 22(4): 659-663.

Maldonado JF. The life history and biology of Platynosomum fastosum Kossak, 1910 (Trematoda, Dicrocoeliidae). PR J Public Health Trop Med 1945; 21(1): 17-39.

O'Sullivan BM, Rosenfeld LE, Green PE. Concurrent infection with Yersinia pseudotuberculosis and Platynosomum fastosum in a cat. Aust Vet J1976; 52(5): 232-233. PMid:786240. http://dx.doi.org/10.1111/j.1751-0813.1976. tb00077.x.

Pinto HA, Mati VLT, Melo AL. New insights into the life cycle of Platynosomum (Trematoda: Dicrocoeliidae). Parasitol Res 2014; 113(7): 2701-2707. PMid:24802870. http://dx.doi.org/10.1007/s00436-0143926-5.

Prophet EB, Mills B, Arrington JB, Sobin LH. AFIP Laboratory Methods in Histotechnology. Washington, DC: Armed Force Registry of Pathology; 1992.

R Development Core Team. R: a language and environment for statistical computing, reference index version 2.14.0. Vienna: $\mathrm{R}$ Foundation for Statistical Computing; 2011 [cited 2016 Oct 18]. Available from http:// www.r-project.org.

Ramos DGS, Scheremeta RGAC, Oliveira ACS, Sinkoc AL, Pacheco RC. Survey of helminth parasites of cats from the metropolitan area of Cuiabá, Mato Grosso, Brazil. Rev Bras Parasitol Vet 2013; 22(2): 201-206. PMid:23856737. http://dx.doi.org/10.1590/S1984-29612013000200040.

Retnasabapathy A, Prathap K. The liver-fluke Platynosomum fastosum in domestic cats. Vet Rec 1971; 88(3): 62-65. PMid:5100594. http:// dx.doi.org/10.1136/vr.88.3.62.

Rodriguez-Vivas RI, Williams JJ, Quijano-Novelo AG, Bolio GM, Torres-Acosta JF. Prevalence, abundance and risk factors of liver fluke (Platynosomum fastosum) infection in cats in Mexico. Vet Rec 2004; 154(22): 693-694. PMid:15200076. http://dx.doi.org/10.1136/vr.154.22.693.

Salomão M, Souza-Dantas LM, Almeida FM, Branco AS, Bastos OPM, Sterman F, et al. Ultrasonography in hepatobiliary evaluation of domestic cats (Felis catus, L., 1758) infected by Platynosomum Looss, 1907. Intern J Appl Res Vet Med 2005; 3(3): 271-279.

Sharif M, Nasrolahei M, Ziapour SP, Gholami S, Ziaei H, Daryani A, et al. Toxocara cati infections in stray cats in northern Iran.J Helminthol 2007; 81(1): 63-66. PMid:17381869. http://dx.doi.org/10.1017/ S0022149X07214117.

Spithill TW, Piedrafita D, Smooker PM. Immunological approaches for the control of fasciolosis. Int J Parasitol 1997; 27(10): 1221-1235. PMid:9394193. http://dx.doi.org/10.1016/S0020-7519(97)00120-3.

Taylor D, Perri SF. Experimental infection of cats with the liver fluke Platynosomum concinnum. Am J Vet Res 1977; 38(1): 51-54. PMid:402094.

Xavier FG, Morato GS, Righi DA, Maiorka PC, Spinosa HS. Cystic liver disease related to high Platynosomum fastosum infection in a domestic cat. J Feline Med Surg 2007; 9(1): 51-55. PMid:17241806. http://dx.doi. org/10.1016/j.jfms.2006.08.006. 